\title{
Search Engine Advertising (SEA) Or Organic Links: Do Customers See The Difference?
}

Andrzej Kobylanski, Penn State Greater Allegheny, USA

\begin{abstract}
This study seeks to investigate the perceptions and attitudes of internet users toward the sponsored link. In light of this study, respondents do not express greater bias with sponsored links in comparison with traditional advertising media, as well as in comparison with organic links. Among factors that mostly affect searchers' attitudes, the informativeness is the critical factor; however, no specific category of information will significantly increase the respondent's likelihood to explore a sponsored link. It is rather text relevance to the keyword typed by the searcher that makes a link attractive. Results also indicate that business students recognize a great value and potential benefits of using search engine advertising as a marketing tool.
\end{abstract}

Keywords: Search Engine; Internet Advertising; Sponsored Links

\section{INTRODUCTION}

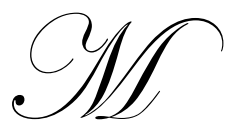

arketers constantly try to find better ways to attract customers to buy or use their products or services using different forms of advertising. Faced with a large number of options of media that are targeting different audiences and operating with budget constraints, marketing managers need to make decisions to efficiently and effectively allocate their resources to achieve the goals of advertising campaigns. Across different media, the popularity of online advertising, particularly search engine advertisement (SEA), is growing (Animesh, Ramachandran, and Viswanathan, 2010). A study conducted by the Interactive Advertising Bureau (IAB) projects that advertisers' spending will grow from \$16.6 billion to \$19.3 billion in 2011 (www.iab.net).

Search engine advertising (SEA) is based on the approach of relevance of the generated links to the keywords typed by the searcher. The search engine generates two types of links as a response to the searcher keyword. One set of results is composed of "organic" (non-sponsored) links that are generated as a natural consequence of proprietary matching algorithm. The second set is formed by the "sponsored" links known as "payper-click (PPC) listing" (Kennedy and Kennedy, 2008). They are displayed as a result of advertising actions of firms, organizations, and individuals who are paying for the keywords that the searcher used in the search query. This second group of links is the actual search engine advertising. The searcher's keywords generate text link listings that become displayed at the top and down the right side of the results page. In most cases, advertisers bid for positions in those listings, paying when a click occurs on their ads directing to the advertiser's website. The growing popularity of this type of advertising is a result of the mechanism of a performance-based model of advertising and displaying targeted ads to the audiences that most likely want to see those messages.

There are a number of discussions in literature that highlight the benefits of using search engine advertisement - targeted message, low cost, ability to adjust the ad quickly, tracking record, and pay-forperformance mechanism. However, there is not much literature about customers' perception of the usefulness of these ads and how managers can improve these messages in order to reach younger demographics - a population segment that is highly involved with the online environment. 
The primary goal of this article is to determine the motivations, attitudes and key patterns of behavior of business college students in regard to search engine advertising. The secondary goal of this project is to explore how business students' personal customer experiences influence their opinion about the usefulness and value of search engine advertising as a marketing tool.

\section{LITERATURE REVIEW}

A fast-paced environment and the emergence of new forms of communication tools used in the online environment have prompted advertisers to thoroughly explore search engine advertising opportunities. The global market of search engine advertising is estimated to reach $\$ 33$ billion in 2011 and is becoming an important component of businesses Integrated Marketing Communications strategies. The growth of online advertising creates a need to investigate the challenges of using sponsored links to reach target markets. Researchers exploring this field often focus their attention on the mechanism of ad placement. There are two streams of research that investigate the auction systems that primarily dominate this form of advertising. One explores advertisers' bidding strategies and keyword selection in order to optimize the relevance of the messages to potential searchers (e.g., Kitts and Leblanc, 2004; Ghose and Yang, 2007; Hosanagar and Schwarz, 2007). The second focuses on mechanisms to optimize the location of the ad in terms of rank within the list of sponsored links (Asdemir, 2006; Edelman et al., 2007; Fenget al., 2007; Weber and Zheng, 2007; Ghos and Yang, 2009). Several works focus on the keyword auctions (Edelman, Ostrovsky, and Schwarz, 2007; Varian, 2007) where the highest bidder gets the best position (slot) in the sponsored links list.

Both tracks address the issue of competition among advertisers striving for greater exposure and consumer attention, which narrows down to knowledge of bidding strategies and advertisers' behavior, which leads to securing the highest position in the generated search results. Studies of Liu, Chen and Whinston (2010) investigated weighting schemes of advertising bids and minimum bid policies established by the keyword search advertising providers. They suggest that advertisers could generate higher revenue by using the search engines that employ the revenue-maximizing weighting scheme rather than systems that employ standard fixed-payment auctions.

Recently, a new stream of research emerged that is finally taking a customer-oriented approach. This trend investigates searchers' behavior and responses to this new form of paid communication. One of the earliest attempts to investigate customer perceptions of advertising in the online environment was a study conducted by Wolin, at al. (2002). The authors explored internet users' beliefs about online advertising and discovered that online users' beliefs affected attitude formation toward online advertising, thus holding a greater likelihood of a favorable response toward Internet ads. Particular studies that investigate customer attitudes toward sponsored and organic search results have been conducted by Jansen and Resnick (2006). Based on the experiment designed for that study, they concluded that although customers have bias against sponsored links, they treat paid adverting as relevant as naturally generated results when they view all generated search results (organic and sponsored). The recent works of Yang and Ghose (2010) focused on the importance of the interrelationship between organic and sponsored search results. Built on the fact that organic search results are being generated based on the user profile and past history of clicks, they indicated that marketers should blend both the organic and paid listings in order to improve customer utility by reducing the cognitive costs associated with evaluating different alternatives (Yang and Ghose, 2010).

There is a growing trend to investigate the attitudinal and cognitive evaluation of sponsored links to estimate critical factors that affect searchers' perceptions. Lin and Hung (2009), based on the model formed by Ducoffe (1996), suggest that the most important factor affecting positive or negative perception is credibility and trustworthiness of the content of the sponsored link, with informativeness having no impact on the searchers' perceptions. They suggest that entertainment and irritations played an important role, but only to the specific group of searchers. Wang and Sun (2010) explored cross-cultural aspects of attitude formation. Although they found that similar factors affect attitudes of searchers in the USA and in Romania, they conformed only partially to earlier findings. In this research, they distinguished another factor that affects a positive attitude toward sponsored links economy. They suggest that economy was the most important factor, stating "those who believe that online advertising has a positive impact on the economy tend to have a positive attitude toward online advertising" (Wang and Sun, 2010). They also contradicted earlier findings suggesting that information was the second strongest predictor of attitude formation. 
We hope that our study will contribute to this stream of research by filling gaps in existing literature. Our research will partially be built on Lin and Hung's (2009) findings; however, it will expand the scope of evaluation not only on sponsored links, but also on organic links, to investigate if the attitudes are only specific toward sponsored links or if they represent a general attitude toward links generated by the search query.

This paper is based on two-part studies conducted among undergraduate business students where we denoted search engine advertising as a "sponsored link" and naturally generated links denoted as "organic links." In terms of achieving the goals of this study, we articulated the following research questions:

Q1: When using a search engine, do business students distinguish sponsored links from organic, and is there a preference of choosing one over another?

Q2: Are searchers biased against sponsored links?

Q3: Which factors are critical to influence usage of sponsored links?

Q4: What type of information included in the sponsored link increases likelihood of exploring this link by the searcher?

Q5: How likely is it that business students would be willing to utilize sponsored links as an advertising platform based on their personal experience as customers?

It appears that among the general population, some searchers do not distinguish differences in presented links when exploring the generated search query. We have assumed that business students represent above-average knowledge about the online environment; therefore, we want to confirm our assumption and investigate their search patterns when conducting online keyword searches. We intend to explore their attention and responsiveness to paid messages versus generic naturally-obtained search results. Thus, we formed the following hypothesis:

H1: When using a search engine, business students consciously choose organic links because they are aware of a difference in categories of generated links.

Works of Jansen and Resnick (2006) suggest strong bias against sponsored links. This is manifested by searchers' preferences to explore organic links over sponsored ones. We would like to confirm if the same assumption is valid for younger demographics - college students. However, we also decided to investigate bias against sponsored links in conjunction with other forms of advertising. It is well documented in the literature (Mehta, 2000; Brackett and Carr, 2001; Wang, Zhang, Choi, and D'Eredita, 2002) that customers are biased against advertising messages. There are a number of factors that affect this situation, but we want to explore only one factor relevant to our research. Customers associate different levels of credibility to advertising messages based on the medium or the media platform in which the ad is presented. Therefore, we desired to explore the credibility and trustworthiness of this new advertising tool in comparison to traditionally-used forms of advertising. Therefore, the hypotheses are as follow:

H2: Business students express bias against sponsored links compared to organic links.

H3: Business students express bias against sponsored links compared with other forms of advertising.

For Q3, we studied to what degree young customers (college students) are responding to advertised messages generated by search engines. We evaluated the form of the ad in the categories of attractiveness and value communicated by the text of the ad, as well as irritation and credibility of the sponsored links. Thus:

H4: Searchers are positively influenced by the value of information delivered by the sponsored link.

H5: Searchers are positively influenced by the attractiveness of the form of the sponsored link. 
H6: Searchers are negatively influenced by the irritation caused by the sponsored link.

H7: Searchers are negatively influenced by the low credibility of the sponsored link.

Assuming that message strategy is critical in every form of advertising, we decided to investigate customer preferences in terms of what type of information included in the sponsored link is more attractive to them and is a predictor of increased probability of link investigation by the searcher. Therefore, we stated:

H8: Specific types of information included in the text ad will influence customer preference to explore the sponsored link.

Based on the business students' individual experience with search engines, and partially influenced by participation in this study, students were forced to rethink their opinion about sponsored links. We wanted to investigate how useful this advertising tool is in the eyes of future business managers. We wanted to explore how positive personal (from the customer side) experience influences their managerial decision. This resulted in the following hypothesis.

H9: Business students that express a positive attitude about sponsored links will use search engine advertising as a viable advertising tool.

This paper is organized as follows: First we discuss the related literature, than we present our research design and data analysis. The next section includes discussion of empirical findings and implications, concluding with suggestions for future research.

\section{METHODS}

The primary goal of this study is to examine perceptions and attitudes of search engine advertising among young people who pursue a business degree. We particularly chose this sample of population because, at this stage in their lives, they experience search engine advertising only from the searcher's position and they often constitute a target audience for this form of advertising. However, we assume that because they pursue education in business, they have above-average knowledge of internet marketing and are much more aware about marketing actions that could be targeting them in the online environment.

In order to achieve these goals, we constructed two studies in which we used surveys as a primary tool for collecting data. The first study focused on general attitude and perception of search engine advertising from the searcher's perspective. This survey was composed of two parts. The first part addressed customer behavior patterns that are associated with the interaction with "sponsored links" and the second part investigated attitudes and assumptions in terms of evaluating the benefits of these form of advertising and factors affecting general perception of sponsored links. For the second study, we used a questionnaire that directly asked searchers about potential benefits and the value of sponsored links as a marketing tool used to improve business performance. For both studies, we created and distributed an online questionnaire using one of the specialized internet services and distributed the link to the survey to students who fall into the profile described earlier. Respondents accessed the first study through the provided link; then after completing the first survey, they were asked to participate in the second study and encouraged to complete a second (shorter) survey. The ability to sequence both studies allows us to track the responses of participants and compare results obtained from both studies. Undergraduate business students at public universities composed the sample population. Table 1 presents descriptive statistics of the sample demographics.

Seventy-one usable surveys were collected from 38 male and 33 female respondents. There were 33 students younger than 21 years old, 31 between the ages of 21 and 29, and seven 30 years or older. The largest group of respondents was majoring in Business Administration (21 students), followed by Management, Marketing, and Corporate Communication (12,9, and 7 students, respectively). Only a few respondents declared majoring in Accounting (4) and Finance (3). There were also12 students exploring other majors. 
Table 1: The Descriptive Statistics of Sample Demographics

\begin{tabular}{|l|l|c|c|}
\hline \multirow{3}{*}{ Gender } & \multicolumn{1}{|c|}{ Number } & Percentage \\
\hline \multirow{5}{*}{ Age } & Male & 38 & $53.5 \%$ \\
\cline { 2 - 4 } & Female & 33 & $46.5 \%$ \\
\hline \multirow{5}{*}{ Student status } & Less than 21 years old & 33 & $46.5 \%$ \\
\cline { 2 - 4 } & $21-29$ & 31 & $43.7 \%$ \\
\cline { 2 - 4 } & Over 30 & 7 & $9.9 \%$ \\
\cline { 2 - 4 } & Freshman/sophomore & 31 & $43.7 \%$ \\
\cline { 2 - 4 } & Junior/senior & 30 & $42.3 \%$ \\
\cline { 2 - 4 } & Other & 11 & $15.5 \%$ \\
\cline { 2 - 4 } & Mariness Administration & 21 & $29.6 \%$ \\
\cline { 2 - 4 } & Management & 9 & $12.7 \%$ \\
\cline { 2 - 4 } & Finance & 12 & $16.9 \%$ \\
\cline { 2 - 4 } & Accounting & 3 & $4.2 \%$ \\
\cline { 2 - 4 } & Corporate Communication & 4 & $5.6 \%$ \\
\cline { 2 - 4 } & Other & 7 & $9.9 \%$ \\
\hline \multirow{3}{*}{ Total } & & 12 & $16.9 \%$ \\
\hline
\end{tabular}

\section{RESULTS}

\section{Search Behavior of Investigated Population}

Among investigated business students, there are only three search engines that constitute this market, with clear domination of google.com (88.6\% of users) and marginal market share for yahoo.com (10\%) and Microsoft's bing.com (5.7\%). Some respondents indicated that they are using more than one search engine without clearly defining which one they use more often. It is interesting that members of this segment are heavy users of this product, with the largest group that uses it constantly (37.1\%), followed by respondents that use it five times or more per day $(33.8 \%)$. Less than one-third $(28.6 \%)$ of this sample use it less than five times per day. This represents a great opportunity for marketers to capture the attention of this attractive audience.

Investigating the usefulness of sponsored links is critical to determine if customers differentiate content of the search results in terms of sponsored or organic results. Using a binomial test $(\mathrm{p}<0.001)$, we found that more than half of the surveyed respondents $(57.4 \%)$ did not pay attention to whether the generated results belonged to one category or the other, compared to the $33.8 \%$ respondents who actually do pay attention (Figure 1). There is also a group of respondents (8.8\%) who did not see a difference between categories of links and treated them as equally important. These results are consistent with previous studies (Wolin at al, 2002) and suggest that the majority will treat both links as equal. This also suggests that paid searching advertising could be free from the generally expressed bias toward advertisement because the majority of searchers do not distinguish naturally generated content (organic results) from paid and fully controlled content (sponsored links).

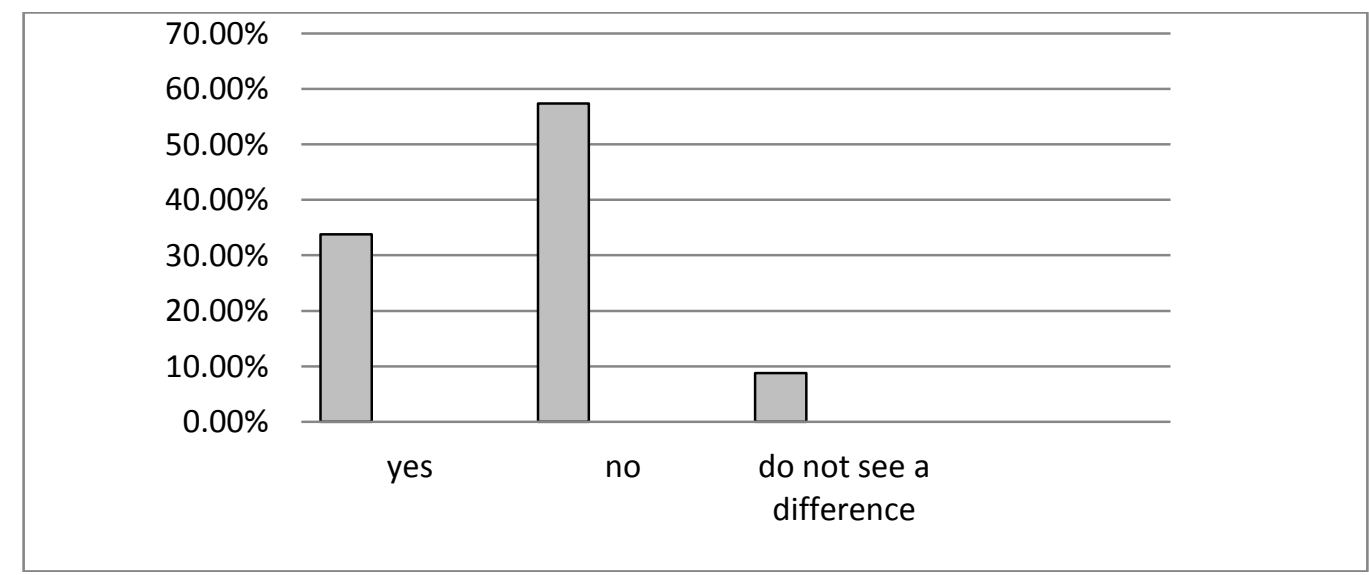

Figure 1: Perception of Differences between Sponsored or Organic Results in a Search Query 
In order to fully address Q1, we conducted a frequency analysis of preferences in search patterns. Results are presented in Table 2 . We asked respondents to express their choices by using a five-point Likert scale where $1=$ strongly disagree and $5=$ strongly agree. We observed that most of the searchers (from overall sample) would click, as a first choice, "link with the highest relevance to search (either sponsored or organic)" with $\mathrm{M}=3.67$. "First link from the list of organic results" was the second strongest choice $(\mathrm{M}=3.53)$, followed closely by the third choice "the first link on the top of the page (either sponsored or organic)" with $\mathrm{M}=3.22$. Therefore, we were not able to observe any signals of strong preference toward organic links. In order to confirm this trend, we conducted analyses of differences of means between groups of users who recognize organic links and those who do not pay attention to this categorization. We were not able to find significant differences between those two groups of searchers. Thus, by combining results of both analyses, we reject Hypothesis 1 - When using a search engine, business students consciously choose organic links because they are aware of a difference in categories of generated links.

Table 2: Search Preferences Based on the Category of the Link (Organic, Sponsored), Location of the Link (First, Last, Top, Bottom, etc.) and Quality Factor (Relevance to Search)

\begin{tabular}{|l|c|c|c|c|c|c|c|c|c|}
\hline \multicolumn{1}{|c|}{ Answer Option } & Overall Sample & \multicolumn{2}{|c|}{ Pay Attention } & \multicolumn{2}{|c|}{$\begin{array}{c}\text { Do Not Pay } \\
\text { Attention }\end{array}$} & t-test & F & p-value \\
\hline & Mean & St Dev. & $\begin{array}{c}\text { Mean1 } \\
\text { N=23 }\end{array}$ & St Dev. & $\begin{array}{c}\text { Mean 2 } \\
\text { N=39 }\end{array}$ & St Dev. & & & \\
\hline $\begin{array}{l}\text { The link with the highest } \\
\text { relevance to your search (either } \\
\text { sponsored or organic) }\end{array}$ & 3.67 & 1.196 & 3.73 & 1.241 & 3.64 & 1.267 & 0.257 & 0.007 & 0.933 \\
\hline $\begin{array}{l}\text { The first link from the organic } \\
\text { search (naturally generated list } \\
\text { of links) }\end{array}$ & 3.53 & 1.059 & 3.87 & 0.968 & 3.41 & 1.093 & 1.665 & 2.158 & 0.147 \\
\hline $\begin{array}{l}\text { The first link on the top of the } \\
\text { page (either sponsored or } \\
\text { organic) }\end{array}$ & 3.22 & 1.183 & 3.0 & 1.069 & 3.26 & 1.309 & -0.800 & 1.366 & 0.247 \\
\hline $\begin{array}{l}\text { The sponsored link with highest } \\
\text { relevance to your search, } \\
\text { regardless of location }\end{array}$ & 3.0 & 1.272 & 2.77 & 1.378 & 3.05 & 1.276 & -0.795 & 0.591 & 0.445 \\
\hline $\begin{array}{l}\text { The randomly selected link from } \\
\text { the generated list }\end{array}$ & 2.68 & 0.984 & 2.67 & 0.796 & 2.56 & 1.046 & 0.392 & 3.278 & 0.075 \\
\hline $\begin{array}{l}\text { The first sponsored link on the } \\
\text { right side of the page }\end{array}$ & 2.46 & 1.158 & 2.23 & 1.152 & 2.44 & 1.165 & -0.674 & 0.011 & 0.917 \\
\hline $\begin{array}{l}\text { The sponsored link in the } \\
\text { middle of the list }\end{array}$ & 2.36 & 1.055 & 2.38 & 1.024 & 2.24 & 1.076 & 0.501 & 0.091 & 0.764 \\
\hline $\begin{array}{l}\text { The last sponsored link on the } \\
\text { first page }\end{array}$ & 2.13 & 0.991 & 2.09 & 0.971 & 2.03 & 1 & 0.244 & 0.165 & 0.686 \\
\hline
\end{tabular}

\section{Bias toward Sponsored Links}

Based on the confirmed assumption that searchers in an analyzed sample mostly do not pay attention if the internet link they want to explore is organic or sponsored, and assuming that the main criterion for the choice is the content and relevance of the link, we suspect that paid search advertising could be free from the generally expressed bias toward advertisement. This depicts a situation where the majority of searchers do not distinguish naturally generated content (organic results) from paid and fully controlled content (sponsored links). This assumption has been confirmed by the analysis of variance presented in Table 2 and resulted in rejection of Hypothesis 2 - Business students express bias against sponsored links and not to organic links.

One of the biggest challenges that marketers are facing is the negative attitude and bias toward advertisement in general. Customers are often skeptical and do not trust messages delivered in the form of advertising. Based on this assumption, we investigated the searcher's perception of credibility of search engine advertising compared with the advertisement placed in other (traditional) media channels. We used a five-point Likert scale $(1=$ "lowest credibility compared to sponsored link" and $5=$ "highest credibility compared to sponsored link"). The results are presented in Figure 2. 


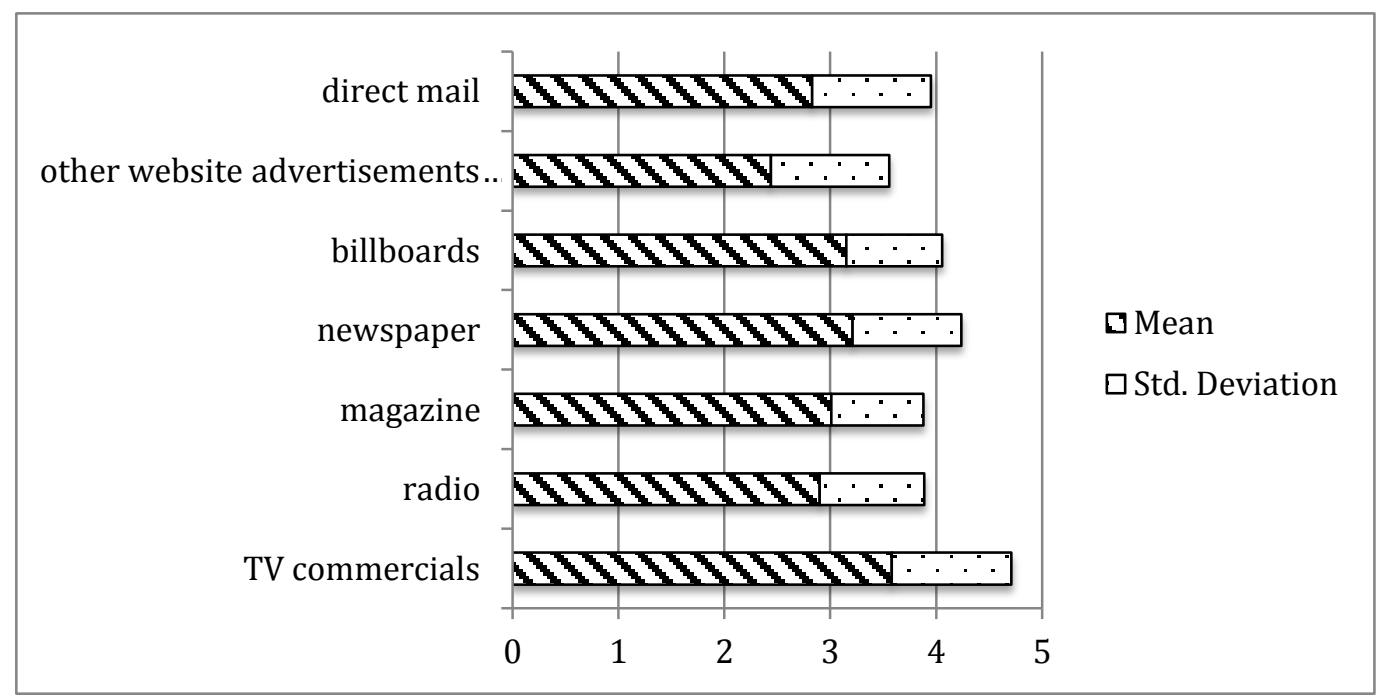

Figure 2: Credibility of Sponsored Links Compared to Other Forms of Advertising

Obtained results indicate that online users perceive search engine advertising as a somewhat credible form of communication with customers. Respondents do not express greater bias toward sponsored links in comparison with traditional media, with the exception of TV ads that scored highest in this assessment $(\mathrm{M}=3.61, \mathrm{SD}=1.154)$. Other media - radio, magazines, newspapers and billboards - are considered almost at the same level in terms of trusting the content of the ads. However, we noticed a very interesting trend - that ads delivered through sponsored links are perceived with higher credibility than other forms of online advertising $(\mathrm{M}=2.38, \mathrm{SD}=1.146)$. Based on these findings, we partially reject Hypothesis 3 - Business students will have a greater bias against sponsored links compared with other forms of advertising.

\section{Critical Factors that Affect Attitude toward Sponsored Links}

In order to fully capture perception of sponsored links and distinguish them from other content generated by search engines, we explored a model introduced by Ducoffe, R. (1996) and further developed by Brackett and Carr (2001), Lin and Hung (2009), and Wang and Sun (2010). We partially adopted previously used categories with sets of subcategories based on antecedent variables - informativeness, entertainment, irritation, and credibility. Unlike previous studies, we decided to test not only attitude formation toward sponsored links, but also toward organic links. Therefore, we attempted to distinguish if these antecedent variables apply to all links triggered by the keyword in the search engine or if they are only specific to sponsored links.

The analysis of t-test suggests a significant difference between searchers perception of organic links and sponsored ones in the informativeness factor (Table 3). It appears that organic links are perceived with a more positive attitude because we observed a significant difference (at $\alpha=0.01$ ) in all subcategories. Thus, we can reject Hypothesis 4 - Searchers are positively influenced by the value of information delivered by sponsored link. When we observed significant differences at $\alpha=0.01$ and $\alpha=0.05$, the second important factor was credibility, suggesting that organic links are perceived with greater credibility because they are believable and searchers usually trust the information carried by organic links. These results create an argument that allows us to support Hypothesis 7 Searchers are negatively influenced by the low credibility of sponsored links.

In terms of entertainment value or attractiveness of the links, the differences between these two groups exists only at the lower level of $\alpha=0.05$ and only in two out of four subsets that have been evaluated by respondents. Searchers evaluating both types of links, in terms of displaying results in an attractive form or sentence, treat them very similar. It suggests that the attractiveness factor is not important to them when they explore content of the links. Interestingly, with a lack of significant differences, both types of links have been perceived to carry built-in weakness. "Results often do not contain information that you are looking for" with means 2.56 (SD = 
1.002) and $2.8(\mathrm{SD}=1.03)$ for organic and sponsored links, respectively. Therefore, we don't have arguments to support Hypothesis 5 - Searchers are positively influenced by the attractiveness of the form of sponsored links.

Table 3: Searcher's Perception of Organic and Sponsored Links

\begin{tabular}{|c|c|c|c|c|c|c|c|}
\hline & \multicolumn{2}{|c|}{ Organic Links } & \multicolumn{2}{|c|}{ Sponsored Links } & \multirow{2}{*}{$\mathbf{t}$} & \multirow{2}{*}{$\mathbf{F}$} & \multirow{2}{*}{ p-value } \\
\hline & Mean & Std. Dev. & Mean & Std. Dev. & & & \\
\hline \multicolumn{8}{|l|}{ Informativeness } \\
\hline $\begin{array}{l}\text { Results are always highly relevant to your } \\
\text { search }\end{array}$ & 3.35 & 1.052 & 2.77 & 0.998 & $3.195 * *$ & 1.223 & 0.271 \\
\hline $\begin{array}{l}\text { Results always provide information that } \\
\text { you are looking for }\end{array}$ & 3.33 & 0.861 & 2.72 & 0.967 & $3.779 * *$ & 0.197 & 0.658 \\
\hline Results always provide timely information & 3.33 & 0.984 & 2.68 & 1.133 & $3.442 * *$ & 1.748 & 0.189 \\
\hline \multicolumn{8}{|l|}{ Entertainment } \\
\hline $\begin{array}{l}\text { Results are always displayed in an } \\
\text { attractive form/sentence }\end{array}$ & 3.17 & 1.062 & 2.86 & 1.22 & 1.546 & 0.908 & 0.342 \\
\hline Generated link is enjoyable & 3.02 & 0.889 & 2.67 & 1.032 & $2.035 *$ & $4.747 * *$ & 0.031 \\
\hline Generated link is pleasing & 3.1 & 0.851 & 2.75 & 0.999 & $2.111 *$ & 2.504 & 0.116 \\
\hline $\begin{array}{l}\text { Results often do not contain information } \\
\text { that you are looking for }\end{array}$ & 2.56 & 1.002 & 2.8 & 1.03 & -1.303 & 0 & 0.993 \\
\hline \multicolumn{8}{|l|}{ Irritation } \\
\hline $\begin{array}{l}\text { Too many generated links make finding } \\
\text { things difficult }\end{array}$ & 3.1 & 1.141 & 3.06 & 1.332 & 0.155 & 2.462 & 0.119 \\
\hline Generated link is annoying & 2.57 & 0.979 & 2.94 & 1.213 & -1.848 & 2.007 & 0.159 \\
\hline Generated link is irritating & 2.48 & 1.02 & 2.98 & 1.143 & $-2.58 * *$ & 0.119 & 0.73 \\
\hline \multicolumn{8}{|l|}{ Credibility } \\
\hline $\begin{array}{l}\text { Results are always the source of credible } \\
\text { information }\end{array}$ & 2.92 & 0.965 & 2.51 & 1.162 & $2.186^{*}$ & $5.048 * *$ & 0.026 \\
\hline $\begin{array}{l}\text { You trust the information under the links } \\
\text { generated by sponsored links }\end{array}$ & 2.98 & 0.932 & 2.5 & 1.155 & $2.583 * *$ & $8.309 * *$ & 0.005 \\
\hline Generated link is believable & 3.16 & 0.902 & 2.54 & 1.058 & $3.503 * *$ & 3.791 & 0.054 \\
\hline
\end{tabular}

$* 0.05, * * 0.01$

The smallest differences in evaluations of organic and sponsored links have been reported in the irritation category where we observed only one subcategory with a significant difference at $\alpha=0.01$, suggesting that content, form or information displayed by sponsored links is much more irritating to the searchers than the same components of an organic link. Considering our hypothesis, we can partially support Hypothesis 6 - Searchers are negatively influenced by the irritation caused by the sponsored link.

Our findings are consistent with results reported by Wang and Sun; however, they partially contradict findings of Lin and Hung, where they suggested that "informativeness was of no importance to the context of a sponsored link." However, taking into consideration the perception of organic links in regard to sponsored links, we observed even greater importance of this factor, suggesting customer preference in exploring organic links before sponsored ones.

\section{Information Included in the Link}

Based on the indication that information included in the sponsored link may direct searchers interest to investigate organic or sponsored links, we took into consideration types of information that could increase the likelihood of exploring sponsored links (Q4). Previous research (Resnick, 2010) suggested that the presence of the keyword in the sponsored link is the most influential information that can stimulate the usage of a link with an advertising message. Our study, however, indicates that no single type of information - like brand name, price, keyword, product info, destination website or association with other known brands - will significantly increase the attractiveness of the sponsored link to the searcher. All of the identified elements included in the link are important to the searchers with means in the range between 3.17 and 3.52 on a five-point scale $(1=$ not important and $5=$ very 
important). These findings are confirmed by the correlation analysis in Table 4. It is evident that all identified information has a positive effect on the perception of the importance of elements displayed by sponsored links. The correlation analysis indicates that "association with other reputable brands" is close to strong positive correlation with price and information about the product at their coefficients correlations of 0.746 and 0.721 , respectively, at the significance level of 0.01 . It suggests that businesses that utilize sponsored links can use association with reputable brands (i.e., name of the products they are selling) and treat this as a silent factor that will serve the purpose of product positioning in terms of quality and status of the product. There is also another close correlation between elements of the keyword, which has a significant relationship with product information and website address - at coefficient correlations of 0.645 and 0.662 , respectively.

Table 4: Means, Standard Deviation and Intercorrelation Matrix

\begin{tabular}{|l|c|c|c|c|c|c|}
\hline $\begin{array}{l}\text { Element Displayed in } \\
\text { the Sponsored Link }\end{array}$ & \multicolumn{2}{|l|}{ Correlations } \\
\hline & $\begin{array}{c}\text { Brand } \\
\text { Name }\end{array}$ & Price & $\begin{array}{c}\text { Keyword } \\
\text { Included }\end{array}$ & $\begin{array}{c}\text { Information } \\
\text { About Product }\end{array}$ & $\begin{array}{c}\text { Website } \\
\text { Address }\end{array}$ & $\begin{array}{c}\text { Association with Other } \\
\text { Reputable Brand }\end{array}$ \\
\hline Brand name & 1 & & & & & \\
\hline Price & $.545^{* *}$ & 1 & & & & \\
\hline Keyword included & $.561^{* *}$ & $.479 * *$ & 1 & & & \\
\hline $\begin{array}{l}\text { Information about } \\
\text { product }\end{array}$ & $.365^{* *}$ & $.597 * *$ & $.645^{* *}$ & 1 & & \\
\hline Website address & $.521^{* *}$ & $.386^{* *}$ & $.662^{* *}$ & $.560^{* *}$ & 1 & \\
\hline $\begin{array}{l}\text { Association with other } \\
\text { reputable brand }\end{array}$ & $.482^{* *}$ & $.746^{* *}$ & $.502^{* *}$ & $.721^{* *}$ & $.559 * *$ & \\
\hline \hline Mean & 3.41 & 3.28 & 3.17 & 3.27 & 3.27 & 1 \\
\hline SD & 1.163 & 1.269 & 1.282 & 1.075 & 1.213 & 3.52 \\
\hline
\end{tabular}

$* 0.05, * * 0.01$

Based on conducted analyses, we reject Hypothesis 8 - Specific type of information included in the text of the ad will influence customer preference to explore sponsored link. However, our findings suggest that researchers often use a description of the product, or variation of the website address, they are looking for as a keyword because they do not have complete information about the product or service.

\section{Business Application of Sponsored Links}

The secondary goal of this study was to investigate a future manager's perception of the business value of a sponsored link as an advertising mechanism. The study has been conducted with the same sample and was completed by business students after completing the first questionnaire. We used a shorter questionnaire that included a series of questions about perception of business aspects of using sponsored links as a marketing tool and questions that address the general attitude toward sponsored links. We used a 5-point Likert scale where $1=$ strongly disagree and $5=$ strongly agree. Descriptive statistics of the responses are included in Table 5 . We purposefully arranged Study 2 to follow Study 1 to influence deeper understanding of the investigated topic. By participating in the first study, students were much more knowledgeable about search engine advertising because they had to evaluate their own experiences with search engines and usage of sponsored links. Therefore, they could focus not only on the evaluation of their personal attitudes, but also on business applications and the effectiveness of this marketing tool. As future managers, some even potentially working in the field of marketing, we asked them how implementation of this tool would reflect on the company reputation and product positioning. We asked students about the perception of quality of advertiser based on the usage of sponsored links in marketing strategy and location of the link. We also looked at perception of the size of the company and reputation. 
Table 5: Business Students' Perception of Sponsored Link as a Marketing Tool

\begin{tabular}{|c|c|c|c|}
\hline & Mean & Std. Deviation & $\mathbf{N}$ \\
\hline The higher the SPONSORED link is placed on the list, the higher quality of the advertiser & 3.02 & 1.088 & 71 \\
\hline Only small firms use SPONSORED links & 2.42 & 0.917 & 71 \\
\hline Only firms that provide low quality service/products use SPONSORED links & 2.62 & 1.034 & 71 \\
\hline Reputable companies should avoid advertising through SPONSORED links & 2.89 & 1.069 & 71 \\
\hline Sponsored link is useful & 3.07 & 1.091 & 71 \\
\hline Sponsored link is valuable & 3.21 & 1.045 & 71 \\
\hline Sponsored link is important & 2.92 & 1.117 & 71 \\
\hline Overall, I like Sponsored links & 2.77 & 1.2 & 71 \\
\hline I consider Sponsored link as a good thing & 2.95 & 1.178 & 71 \\
\hline $\begin{array}{l}\text { I would use sponsored links to advertise my own business (company I work/I will be } \\
\text { working for) }\end{array}$ & 3.26 & 1.042 & 71 \\
\hline
\end{tabular}

Search engine algorithms are designed to generate organic results in ways that are most beneficial to the searchers (Kennedy and Kennedy, 2008) by giving priority in listings to the sites most relevant to the keyword used by the searchers. Thus, customer perception of sponsored links could be influenced by the assumptions that most relevant results to the keyword would be listed at the top of the query. However, search engine advertising is based not only on the quality of the keywords, but also on a bidding mechanism and the ability to "purchase" a specific keyword. There could be an assumption that the higher the sponsored link is placed on the list, the higher the quality of the advertiser because companies with greater budgets can financially outperform competitors. We decided to investigate this topic because works of Animesh, Ramachandran and Viswanathan (2010) suggested that by mastering keyword strategies, low quality sellers could obtain top ranks in the search listing and therefore lower the utility of such a mechanism for consumers. Among respondents of this study, over one-third agreed $(34.3 \%)$ or strongly agreed $(4.5 \%)$ with the statement, whereas a slightly lower group disagreed $(22.4 \%)$ or strongly disagreed (10.4\%). We observed that business students do not evaluate this issue only in one dimension. Other questions included in the questionnaire allowed us a deeper understanding of the situation. More than half the students (55.2\%) indicated that they do not believe that only companies with low quality products or services use search engine advertising. Comparing this with $23.9 \%$ that think otherwise, we notice a positive trend in perception of this form of advertising. However, participants in this study had difficulty assessing whether or not reputable companies should use search engine advertising. We obtained a similar level of responses from those who agreed, disagreed or had no opinion on this subject $(29.9 \%, 23.9 \%$, and $31.3 \%$, respectively). Finally the majority of students (59.1\%) did not perceive that only small firms implement search engine advertising in promotional campaigns. Based on this information, we observe a positive attitude in regard to the value of sponsored links as a business tool. Further questions confirmed these findings with most students describing sponsored links as useful and valuable (45.5\% and $46.3 \%$ responses, respectively). On the other hand, students had problems deciding about the importance of this advertising tool and their own feelings toward it. We recorded the lowest scoring answers in two categories that questioned attitudes toward search engine advertising ("sponsored link is important": $M=2.92$ and "I like sponsored links": $M=2.77$ ). It can suggest that at this life stage, business students are much more focused on their own experiences as customers and still need to learn more about the mechanisms of managing search engine advertising campaigns. However, considering the last statement we inquired about - "would you use sponsored links to advertise your own business?" - we see that students are positive about the value and potential benefits of this medium. A prevailing group of respondents $(44.8 \%)$ agreed with the statement and $6 \%$ strongly agreed they will use it in the future. We observed a slightly weaker resistance from students with $10.4 \%$ strongly disagreed with the statement and $7.5 \%$ just disagreed. However, $31.3 \%$ of the students were undecided as to whether this would be an accurate tool to implement in the business environment. Our analyses reveal that we can support Hypothesis 9 Business students that express a positive attitude about sponsored links will use search engine advertising as a viable advertising tool. A conducted correlation analysis (Table 6) strongly supports our findings. 
Table 6: Means, Standard Deviation and Intercorrelation Matrix

\begin{tabular}{|l|c|c|c|c|c|c|}
\hline & $\begin{array}{c}\text { Sponsored } \\
\text { Link is } \\
\text { Useful }\end{array}$ & $\begin{array}{c}\text { Sponsored } \\
\text { Link is } \\
\text { Valuable }\end{array}$ & $\begin{array}{c}\text { Sponsored } \\
\text { Link is } \\
\text { Important }\end{array}$ & $\begin{array}{c}\text { I Like } \\
\text { Sponsored } \\
\text { Links }\end{array}$ & $\begin{array}{c}\text { It is A } \\
\text { Good } \\
\text { Thing }\end{array}$ & $\begin{array}{c}\text { I Will Use } \\
\text { in the } \\
\text { Future }\end{array}$ \\
\hline Sponsored link is useful & 1 & & & & \\
\hline Sponsored link is valuable & $.576^{* *}$ & 1 & & & & \\
\hline Sponsored link is important & $.689^{* *}$ & $.616^{* *}$ & 1 & & & \\
\hline Overall, I like sponsored links & $.685^{* *}$ & $.640^{* *}$ & $.791^{* *}$ & 1 & & \\
\hline I consider sponsored link as a good thing & $.803^{* *}$ & $.564^{* *}$ & $.816^{* *}$ & $.733^{* *}$ & 1 & \\
\hline $\begin{array}{l}\text { I would use sponsored links to advertise } \\
\text { my own business (company I work/I will } \\
\text { be working for) }\end{array}$ & $.696^{* *}$ & $.683^{* *}$ & $.623^{* *}$ & $.699^{* *}$ & $.694^{* *}$ & 1 \\
\hline & & & & & \\
\hline M & 3.07 & 3.21 & 2.92 & 2.77 & 2.95 & 3.26 \\
\hline SD & 1.091 & 1.045 & 1.117 & 1.200 & 1.178 & 1.042 \\
\hline
\end{tabular}

$* 0.05, * * 0.01$

\section{CONCLUSIONS}

Overall, our results indicate positive attitudes and beliefs toward search engine advertising. In this research, we analyzed consumers' perceptions, beliefs and attitudes toward search engine advertising. Our aim was to understand the perceived differences between search engine advertising and organic results for both brand building and directional purposes, as well as to investigate the attractiveness of this advertising tool to future business/marketing managers. We believe that search engine advertising has the potential to better support goaloriented consumers, thus providing great potential for internet-based directional advertising. We hope that this research will contribute to a better conceptual understanding of consumers' perceptions by extending the existing frameworks. Meanwhile, the study provides practical suggestions on how to manage search engine advertising to fully utilize the advantages of internet-based media.

Our findings suggest that searchers in analyzed samples mostly do not pay attention to whether the internet link they want to explore is organic or sponsored and take the informativeness factor as the main criteria for the choice of the link. Thus, a positive attitude is formed based on the content and relevance of the link. Although no single category of information increases the likelihood of exploring a sponsored link, high relevance to the keyword searched by the customer is a main factor that even overcomes a bias held against any advertising message. It means that a sponsored link could be as attractive as a naturally generated organic link if it satisfies the customer's requirement of relevance.

As to the second goal of this research to explore business students' opinions about the usefulness and value of search engine advertising as a marketing tool, we obtained a clear picture. Based on students' personal experiences as customers, a significant group of students indicated that search engine advertising would be an accurate tool to implement in the business environment.

\section{AUTHOR INFORMATION}

Andrzej Kobylanski is an Assistant Professor of Marketing at The Pennsylvania State University. He holds an MBA from North Dakota State University (USA) and a Ph.D. degree from the University of Warmia and Mazury in Olsztyn (Poland). His current research interests focuses on consumer behavior, customer satisfaction management and search engine marketing. E-mail: auk20@psu.edu.

\section{REFERENCES}

1. Animesh, A., V. Ramachandran, and S. Viswanathan (2010) "Quality Uncertainty and the Performance of Online Sponsored Search Markets: An Empirical Investigation,” Information Systems Research 21(1), 190201. 
2. Asdemir, K. (2006) "Bidding patterns in search engine auctions," Proc. 2nd Workshop on Sponsored Search Auctions, ACM Electronic Commerce, Ann Arbor, MI.

3. Brackett, L.K., and B.N. Carr (2001) "Cyberspace Advertising vs. Other Media: Consumer vs. Mature Student Attitudes," Journal of Advertising Research, 41(5), 23-33.

4. Chen, J., De Liu and A.B. Whinston (2009), Auctioning Keywords in Online Search," Journal of Marketing, 73 (July), 125-141.

5. Ducoffe, R. (1996) "Advertising Value and Advertising on the Web," Journal of Advertising Research, 36(5), 21-34.

6. Edelman, B., M. Ostrovsky, and M. Schwarz (2007) "Internet advertising and the generalized second price auction: Selling billions of dollars worth of keywords," American Economist Review, 97(1), 242-259.

7. Feng, J., H.K. Bhargava, and D.M. Pennock (2007) "Implementing sponsored search in Web search engines: Computational evaluation of alternative mechanisms," Computing 19(1), 137-148.

8. Ghose, A. and S. Yang (2007) "An empirical analysis of paid placement in online keyword advertising," Proc. 9th Internat. Conf. Electronic Commerce, Minneapolis, 95-96.

9. Hosanagar, K. and M. Schwarz (2007) "Tutorial on sponsored search," Proc. 8th ACM Conf. Electronic Commerce, San Diego, 369.

10. Jansen, B. and M. Resnick (2006) "An Examination of Searcher's Perceptions of Nonsponsored and Sponsored Links during Ecommerce Web Searching," Journal of the American Society for Information Science and Technology, 57, (14) 1949-1961.

11. Kennedy, K. and B.B. Kennedy (2008) “A small company's dilemma: using search engines effectively for corporate sales," Management Research News, 31(10), 737-745.

12. Kitts, B. and B. Leblanc (2004) "Optimal bidding on keyword auctions," Electronic Markets 14(3), 186201.

13. Lee, K. and C. Seda (2009) "Search Engine Advertising: Buying Your Way to the Top to Increase Sales By New Riders"

14. Lin, F-H. and Y-F. Hung (2009) "The Value of and Attitude toward Sponsored Links for Internet Information Searchers," Journal of Electronic Commerce Research, 10 (4), 235-251.

15. Liu, D., J. Chen, and A.B. Whinston (2010) "Ex Ante Information and the Design of Keyword Auctions" Information Systems Research 21(1), 133-153.

16. Mehta, A. (2000) "Advertising attitudes and advertising effectiveness," Journal of Advertising Research, 40, 67-72.

17. Schlosser, A.E., S. Shavitt and A. Kanfer (1999) "Survey of Internet users' attitudes toward Internet advertising," Journal of Interactive Marketing, 13(3), 34-54.

18. Wang, Y. and S. Sun (2010) "Examining the role of beliefs and attitudes in online advertising. A comparison between the USA and Romania," International Marketing Review, 27(1), 87-107.

19. Wang, Y., Zhang, Choi, and D’Eredita, (2002) “Understanding Consumers Attitude Toward Advertising," Eighth Americas Conference on Information Systems, Human-Computer Interaction Studies in MIS.

20. Weber, T. and Z. Zheng (2007) "A model of search intermediaries and paid referrals," Information Systems Resources 18(4), 414-436.

21. Wolin, L., P. Korgaonkar and D. Lund (2002), "Beliefs, attitudes and behavior towards web advertising," International Journal of Advertising, 21, 87-113.

22. Varian, H.R. (2007) “Position auctions," International Journal of Industrial Organization, 25(6), 11631178. 